\title{
A polymorphism in gasdermin $B(G S D M B)$ gene is associated with severe asthma exacerbations in childhood: A population-based birth cohort study
}

\author{
Aida Semic-Jusufagic, Angela Simpson, Jenny Hankinson, Adnan Custovic
}

The University of Manchester

Manchester Academic Health Science

Centre, NIHR Translational Research

Facility in Respiratory Medicine

University Hospital of South Manchester

NHS Foundation Trust, Manchester, UK

Corresponding author:

Adnan Custovic

University of Manchester

University Hospital of South

Manchester NHS

Foundation Trust, Second Floor

Education and Research Centre,

Manchester M23 9LT, UK

adnan.custovic@manchester.ac.uk

Tel.: + 44 (0) 1612915869

Fax : + $44(0) 1612915806$

Received: 29 July 2011

Accepted: 10 September 2011

Copyright (C) 2011 by

Academy of Sciences and Arts

of Bosnia and Herzegovina.

E-mail for permission to publish:

amabih@anubih.ba
Rationale. Markers on chromosome 17q12 have been associated with childhood asthma in genome-wide association studies. Objective. We investigated the association of a single nucleotide polymorphism (SNP) in GSDMB (rs7216389) on $17 \mathrm{q} 12$ with asthma presence and severity in a population-based birth cohort study. Methods. Children were followed from birth to age 8 years. Data on parentally-reported symptoms were collected using an interviewer-administered questionnaire at age 1, 3, 5 and 8 years. Atopy was assessed by skin testing at age 3,5 and 8 years. Information on asthma/wheeze hospital admissions and severe asthma exacerbations was collected from child's primary care medical record. Data were analyzed as a recessive genetic model, with T-allele homozygotes as the risk group. Results. Compared to C allele carriers, T-allele homozygotes of rs7216389 were significantly more likely to: wheeze at age 3,5 and 8 years; have persistent wheeze (OR 1.69, 95\% CI 1.05-2.71, p=0.03); have frequent episodes of wheezing and be on asthma medication. In a multiple logistic regression model adjusted for gender, atopic sensitisation and maternal smoking, $\mathrm{T}$ allele homozygotes were significantly more likely to be hospitalized (aOR 2.20 [1.22-3.99], $\mathrm{p}=0.0009$ ) with Cox regression hazard ratio for T-allele homozygotes of 1.94 [1.13-3.33], $\mathrm{p}=0.016$. Results of Cox regression analysis investigating the effect of genotype on the age of first severe exacerbation of asthma indicated an overall hazard ratio of severe asthma exacerbation among T-allele homozygotes of 1.53 [1.04-2.27], $p=0.03$. Conclusions. This is the first population-based birth cohort study to confirm that the risk of childhood wheeze and severe asthma/wheeze exacerbations is increased among rs7216389 TT homozygotes.

Key words: Childhood asthma, Genetics, rs7216389, GSDMB, ORMDL3.

\section{Introduction}

Twin and family studies indicate the strong genetic component of asthma (1). However, despite intensive work 
ranging from family linkage and candidate gene association studies, through to genome-wide association studies (GWAS), genetic studies have produced heterogeneous results with little replication (2). Numerous genes and gene regions have been associated with asthma, e.g. Ober et al in their review in 2006, identified over a 100 genes which have been associated with asthma and atopy-related phenotype, of which 79 have been replicated in more than one population (2). The first GWAS on asthma published in 2007 identified a region on chromosome $17 \mathrm{q} 21$, where 7 of the 12 markers below $1 \%$ false discovery rate threshold mapped to a $112 \mathrm{~kb}$ region (3). Although several single nucleotide polymorphisms (SNPs) were associated with childhood asthma in this study, the strongest statistical association was with rs7216389 SNP in Gasdermin B (GSDMB, also known as GS$D M L)$ gene. Measurement of the global gene expression levels in lymhoblastoid cell lines revealed the same SNP (rs7216389) to be positively associated with transcript levels of orosomucoid-1 like 3 (ORMDL3) gene, suggesting that ORMDL3 expression may be regulated by this GSDMB SNP (3). The rs7216389 SNP lies in the intronic region of GSDMB, approximately $100 \mathrm{~kb}$ downstream of ORMDL3, which is why it has sometimes been referred to as the ORMDL3 SNP. The roles of both GSDMB and ORMDL3 genes are unknown; GSDMB is a member of the Gasdermin family ( $G s d m$ ) of genes that are expressed in skin and gastrointestinal tract epithelium (4). Gsdm family has been linked to gastrointestinal malignancies and a recent study suggested that GSDMB could play a role in stem cell proliferation (5). The ORM$D L 3$ belongs to a family of genes that encode transmembrane proteins of endoplasmic reticulum (ER) and is thought to be involved in protein folding (6).

Since the original GWA study (3), the association between childhood asthma and rs7216389 has been replicated in several case-control and family-based studies conducted in different populations (7-11). A case-control study investigating the association between polymorphisms in this SNP and asthma in children and young adults found that $\mathrm{T}$ allele was significantly more common among subjects with asthma (12). Moreover, TT genotype was a significant predictor of severe asthma exacerbations in school age children. A selected birth-cohort study of children born to asthmatic mothers extended these findings by showing the association of TT genotype with early rather than late-onset wheeze (13). We investigated the association of this common SNP in GSDMB (rs7216389) with asthma and wheeze within a population-based birth cohort study in which meticulous longitudinal phenotyping has been carried out from birth to age 8 years.

\section{Methods}

\section{Study design, setting and participants}

The Manchester Asthma and Allergy Study is an unselected population-based birth cohort described in detail elsewhere (14-18). Parents gave written informed consent and children their assent as appropriate, including the permission to collect data held in primary care records. The study was approved by the Local Ethics Committee and is registered as ICRCTN72673620.

\section{Data sources}

Clinical follow-up: Subjects were recruited prenatally and followed prospectively, attending clinical follow-ups at ages 1, 3, 5 and 8 years ( \pm 4 weeks) (14-18). Information on parentally-reported symptoms and medication used at each follow-up was collected using interviewer-administered validated questionnaires. Physical examination 
was carried out to confirm the presence of eczema.

Primary care data extraction: UK primary care physicians (General Practitioners-GPs) are legally required to maintain accurate records of all health-care encounters of their patients, including retention of hospital admission discharge letters, outpatient appointments and all prescriptions; this medical record follows the patient as they change GP. A trained paediatrician (ASJ) extracted all data from electronic and paper-based records on hospital admissions for wheeze/asthma, with child's age (in days) at admission.

\section{Definition of variables Clinical follow-up}

Current wheeze: defined as a positive answer to the question "Has your child had wheezing or whistling in the chest in the last 12 months?"

Wheeze phenotypes: based on prospectively collected data, children were assigned as No wheezing (no wheezing ever at any follow-up by age eight), Transient early wheezing (wheezing only during the first three years of life), Intermittent wheezing (wheezing at one time point only during first five years or at age eight only), Late-onset wheezing (wheezing started after age three years) and Persistent wheezing (wheezing during the first three years, wheezing in the previous 12 months at age five and eight) $(19,20)$.

Atopic sensitization: ascertained by skin prick testing to common inhalant and food allergens at age 3, 5 and 8 years (21); sensitisation was defined as a mean wheal diameter $3 \mathrm{~mm}$ greater than negative control to at least one allergen.

Eczema: Current eczema was defined as a positive answer to the question "Has your child had an itchy rash coming and going for at least six months". Eczema was confirmed by physical examination at age 3,5 and 8 year follow-up visits.
Current rhinitis: defined as sneezing or runny or blocked nose in the absence of cold or chest infection in the previous 12 months at age 5 and 8 years.

\section{Primary care data extraction}

Admission for asthma/wheeze in the first year of life: dichotomous outcome confirming whether the child was hospitalized for asth$\mathrm{ma} /$ wheeze by age 12 months.

Admission for asthma/wheeze after the first year of life: dichotomous outcome confirming whether the child was hospitalized for asthma/wheeze after the $1^{\text {st }}$ year of life.

Admission for asthma/wheeze in the first eight years of life: any hospital admission for asthma/wheeze in the first eight years of life.

Age at the first admission for asthmal wheeze: age of child (in days) at the first hospital admission.

Severe asthma/wheeze exacerbations: we used the American Thoracic Society definition (22) of either receipt of oral steroids for at least 3 days or admission to hospital or emergency department visit because of asthma/wheeze requiring oral steroid use.

\section{Genotyping}

SNP rs7216389 on chromosome 17q21 was selected for genotyping based on the association with childhood asthma from previous studies $(3,13)$.

Genomic DNA was extracted from blood (phenol-chlorophorm method), saliva (Oragene ${ }^{\oplus}$-DNA Self-Collection Kit, following manufacturer's instructions) or buccal swab samples (whole Genome Amplification reaction with Illustra GenomiPhi V2 DNA Amplification $\mathrm{kit}^{\mathrm{sm}}$ [GE Healthcare], followed by purification using Illustra $\mathrm{Mi}$ croSpin G-50 Columns ${ }^{\mathrm{Tx}}$ [GE Healthcare]).

Genotyping was performed using the Single Base Extension method Sequenom MassARRAY ${ }^{\odot}$ iPLEX $^{\text {mi }}$ Gold system (Hamburg, Germany), combining a primer exten- 
sion reaction chemistry with MALDI-TOF mass spectrometry (23-25). Genotyping calls were made with MassARRAY ${ }^{\odot}$ Typer Analyser realtime software.

\section{Statistical analysis}

Data were analysed as a recessive genetic model, with $\mathrm{T}$ allele homozygotes as the risk group. Single time-point categorical associations were assessed using chi-squared test and logistic regression models. Longitudinal analyses were performed by Generalized Estimating Equations (GEE) using the exchangeable correlation structure and the logit link function.

We investigated the effect of genotype on the age of first severe exacerbation of asth$\mathrm{ma} /$ wheezing resulting in admission to hospital using Cox regression and Kaplan-Meier curves. The children were retained in the analysis from birth until age at the first admission to hospital, drop-out, or age 8 years, whichever came first. SPSS 15.0 was used for all analyses. All estimates are reported with $95 \%$ confidence intervals $[\mathrm{CI}]$ in brackets.

\section{Results}

\section{Participants}

Genotyping success rate was $96.8 \%$. Observed genotype frequencies did not deviate significantly from expected frequencies under the Hardy-Weinberg Equilibrium assumption and were consistent with other populations (26\% TT, $48 \% \mathrm{CT}, 26 \% \mathrm{CC})$. Of the 959 children who were successfully genotyped, 116 took part in an intervention study (26-28) and were excluded from further analysis, as were 41 non-Caucasian children. Clinical follow up data was available on 780 children at age 1, 764 at age 3 years, 778 at age 5 years and 765 at age 8 years; 696 participants had data available on hospital admissions for wheeze/asthma from the primary care records. All evaluable data is presented at each time point.

\section{Descriptive data}

Among 765 children who had data on the rs7216389 genotype and longitudinal wheeze phenotypes, 332 (43.4\%) never wheezed, 194 (25.4\%) had transient wheeze, 92 (12.0\%) intermittent wheeze, 43 (5.6\%) late-onset and 104 (13.6\%) persistent wheeze. Inhaled corticosteroids were used by $91 / 762(11.9 \%)$ children at age 5 and $66 / 767(8.6 \%)$ at age 8 years, and inhaled bronchodilators by $152 / 762(19.9 \%)$ at age 5 and $116 / 802(14.5 \%)$ at age 8 years.

A total of 55/696 children (7.9\%) had been hospitalized for wheeze/asthma at least once during the first 8 years of life; 38 (5.5\%) were admitted once and 17 (2.4\%) were admitted two or more times; 111/696 children (15.9\%) had at least one severe asthma exacerbation in the first 8 years of life.

Atopy was present in 141/673 (21\%) children at age $3,197 / 723(27.2 \%)$ at age 5 and $213 / 717(29.7 \%)$ at age 8 years. Current rhinitis was reported by $215 / 769$ (28.0\%) children at age 5 and 212/762 (27.8\%) at age 8 years.

\section{Outcome data}

Tables 1 summarizes clinical outcomes by rs7216389 in the cohort.

Current wheeze: There was no significant association between genotype and wheezing in the first year of life, whilst at ages 3, 5 and 8 we observed trends for $\mathrm{T}$ allele homozygotes to have more wheezing than $\mathrm{C}$ allele carriers. In multiple logistic regression models adjusted for gender and concurrent sensitization, T allele homozygotes were significantly more likely to have current wheezing at age 5 (adjusted OR 1.47 [1.00-2.17], $\mathrm{p}=0.05)$ and age 8 (aOR 1.64 [1.05-2.58], $\mathrm{p}=0.03$ ), with a strong trend observed at age 3 years (aOR 1.47 [0.99-2.18], $\mathrm{p}=0.055$ ). 
Table 1 Respiratory clinical outcomes by rs7216389 SNP in the cohort

\begin{tabular}{|c|c|c|c|c|}
\hline Outcomes & TT & $\mathrm{CC}+\mathrm{CT}$ & OR $(95 \% \mathrm{Cl})$ & $P$ value \\
\hline Current wheeze age 1 year $(n=780)$ & $\begin{array}{l}74 / 204 \\
(36.3 \%)\end{array}$ & $\begin{array}{l}204 / 576 \\
(35.4 \%)\end{array}$ & $\begin{array}{l}1.04 \\
(0.74-1.44)\end{array}$ & 0.83 \\
\hline Current wheeze age 3 years $(n=764)$ & $\begin{array}{l}58 / 201 \\
(28.9 \%)\end{array}$ & $\begin{array}{l}129 / 563 \\
(22.9 \%)\end{array}$ & $\begin{array}{l}1.36 \\
(0.94-1.96)\end{array}$ & 0.09 \\
\hline Current wheeze age 5 years $(n=778)$ & $\begin{array}{l}55 / 202 \\
(27.2 \%)\end{array}$ & $\begin{array}{l}121 / 576 \\
(21.0 \%)\end{array}$ & $\begin{array}{l}1.40 \\
(0.97-2.03)\end{array}$ & 0.07 \\
\hline Current wheeze age 8 years $(n=765)$ & $\begin{array}{l}44 / 202 \\
(21.8 \%)\end{array}$ & $\begin{array}{l}91 / 563 \\
(16.2 \%)\end{array}$ & $\begin{array}{l}1.44 \\
(0.97-2.16)\end{array}$ & 0.07 \\
\hline $\begin{array}{l}\text { Wheeze phenotypes }(n=765) \\
\text { Never }(n=332) \\
\text { Transient }(n=194) \\
\text { Intermittent }(n=92) \\
\text { Late- onset }(n=43) \\
\text { Persistent }(n=104)\end{array}$ & $\begin{array}{l}82 / 202(40.6 \%) \\
47 / 202(23.3 \%) \\
26 / 202(12.9 \%) \\
10 / 202(5.0 \%) \\
37 / 202(18.3 \%) \\
\end{array}$ & $\begin{array}{l}250 / 563(44.4 \%) \\
147 / 563(26.1 \%) \\
66 / 563(11.7 \%) \\
33 / 563(5.9 \%) \\
67 / 563(11.9 \%) \\
\end{array}$ & $\begin{array}{l}0.98(0.65-1.47) \\
1.20(0.72-2.02) \\
0.92(0.44-1.96) \\
1.68(1.05-2.70)\end{array}$ & $\begin{array}{l}0.9 \\
0.5 \\
0.8 \\
0.03 \\
\end{array}$ \\
\hline Bronchodilator usage age 5 years $(n=762)$ & $\begin{array}{l}54 / 198 \\
(27.3 \%)\end{array}$ & $\begin{array}{l}98 / 564 \\
(17.4 \%)\end{array}$ & $\begin{array}{l}1.78 \\
(1.21-2.61) \\
\end{array}$ & 0.003 \\
\hline Inhaled corticosteroid usage age 5 year $(n=762)$ & $\begin{array}{l}32 / 198 \\
(16.2 \%)\end{array}$ & $\begin{array}{l}59 / 564 \\
(10.5 \%)\end{array}$ & $\begin{array}{l}1.65 \\
(1.04-2.63)\end{array}$ & 0.03 \\
\hline Bronchodilators usage age 8 year $(n=802)$ & $\begin{array}{l}39 / 209 \\
(18.7 \%)\end{array}$ & $\begin{array}{l}77 / 593 \\
(13.0 \%)\end{array}$ & $\begin{array}{l}1.54 \\
(1.01-2.34)\end{array}$ & 0.045 \\
\hline Inhaled corticosteroid usage age 8 year $(n=767)$ & $\begin{array}{l}25 / 203 \\
(12.3 \%)\end{array}$ & $\begin{array}{l}41 / 564 \\
(7.3 \%)\end{array}$ & $\begin{array}{l}1.79 \\
(1.06-3.03)\end{array}$ & 0.03 \\
\hline $\begin{array}{l}\text { Admission to hospital for asthma/ wheeze by age } 8 \\
\text { years }(n=696)\end{array}$ & $\begin{array}{l}22 / 181 \\
(12.2 \%)\end{array}$ & $\begin{array}{l}33 / 515 \\
(6.4 \%)\end{array}$ & $\begin{array}{l}2.02 \\
(1.15-3.57)\end{array}$ & 0.01 \\
\hline $\begin{array}{l}\text { Admission to hospital for asthma/ wheeze in the } \\
\text { first year of life }(n=696)\end{array}$ & $\begin{array}{l}10 / 181 \\
(5.5 \%)\end{array}$ & $\begin{array}{l}16 / 515 \\
(3.1 \%)\end{array}$ & $\begin{array}{l}1.82 \\
(0.81-4.10)\end{array}$ & 0.1 \\
\hline $\begin{array}{l}\text { Admission to hospital for asthma/ wheeze after the } \\
\text { first year of life ( } n=696)\end{array}$ & $\begin{array}{l}16 / 181 \\
(8.8 \%)\end{array}$ & $\begin{array}{l}19 / 515 \\
(3.75)\end{array}$ & $\begin{array}{l}2.53 \\
(1.27-5.04)\end{array}$ & 0.008 \\
\hline $\begin{array}{l}\text { Severe asthma/wheeze exacerbations by age } 8 \\
\text { years }(n=696)\end{array}$ & $\begin{array}{l}38 / 181 \\
(21.0 \%)\end{array}$ & $\begin{array}{l}73 / 515 \\
(14.2 \%)\end{array}$ & $\begin{array}{l}1.61 \\
(1.04-2.49)\end{array}$ & 0.03 \\
\hline $\begin{array}{l}\text { Severe asthma/wheeze exacerbations in the first } \\
\text { year of life }(n=696)\end{array}$ & $\begin{array}{l}10 / 181 \\
(5.5 \%)\end{array}$ & $\begin{array}{l}23 / 515 \\
(4.5 \%)\end{array}$ & $\begin{array}{l}1.25 \\
(0.58-2.68)\end{array}$ & 0.5 \\
\hline $\begin{array}{l}\text { Severe asthma/wheeze exacerbations after the } \\
\text { first year of life }(n=696)\end{array}$ & $\begin{array}{l}34 / 181 \\
(18.8 \%)\end{array}$ & $\begin{array}{l}67 / 515 \\
(13.0 \%)\end{array}$ & $\begin{array}{l}1.55 \\
(0.98-2.43)\end{array}$ & 0.06 \\
\hline
\end{tabular}

$\mathrm{TT}=$ mutant homozygote; $\mathrm{CC}=$ wild type homozygote; $\mathrm{CT}=$ heterozygote .

In a longitudinal model (including data from ages 3,5 and 8 ), we found a significant association between genotype and development of wheezing, with $\mathrm{T}$ allele homozygotes being significantly more likely to have wheezed throughout childhood (OR 1.36 [1.04-1.84], $\mathrm{p}=0.02)$.

Phenotypes of wheeze: Compared to children who had never wheezed, persistent wheezers were significantly more likely to be
T allele homozygotes (OR 1.69 [1.05-2.71], $\mathrm{p}=0.03)$. We found no association between genotype and late-onset wheeze $(\mathrm{p}=0.8)$ or transient early wheeze $(\mathrm{p}=0.9)$.

Wheeze frequency: $\mathrm{T}$ allele homozygotes were significantly more likely to have had frequent episodes of wheezing in the last 12 months at age 8 years than other genotype groups (e.g. 4 or more wheezy episodes, TT $9 \%$ vs. CC+CT $4.3 \%$, $\mathrm{p}=0.04$ ) 


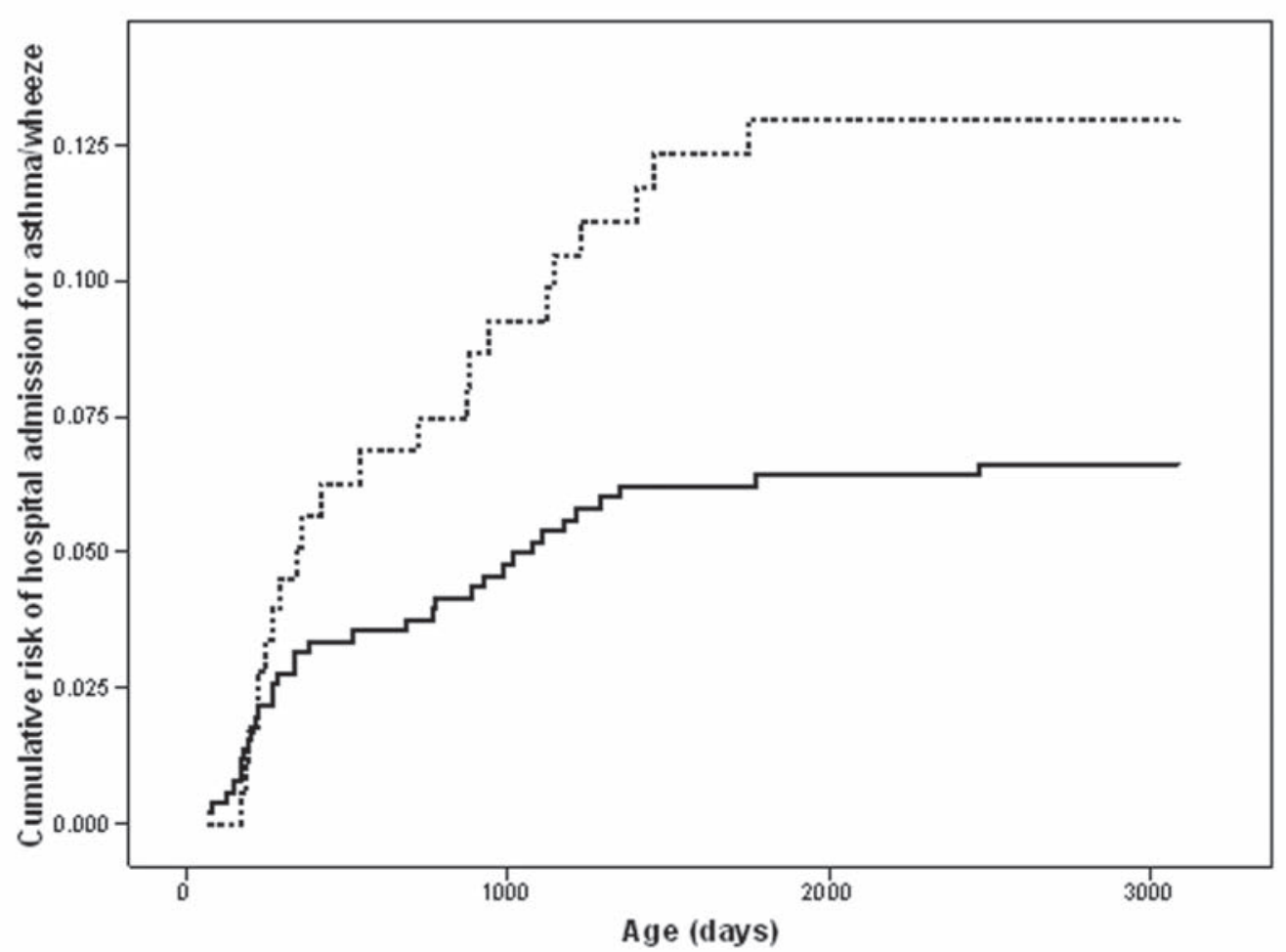

Figure 1 Kaplan-Meier Estimates of Cumulative Risk of hospital admission with wheeze/asthma in two rs7216389 genotype groups. Dashed line: TT homozygotes; Solid line: CT heterozygotes + CC homozygotes

Asthma medication: The use of both bronchodilators and inhaled corticosteroids at ages 5 and 8 years was significantly more common amongst children who were $\mathrm{T}$ allele homozygotes compared to $\mathrm{C}$ allele carriers (Table 1).

\section{Hospital admission for asthma/wheeze}

The proportion of children admitted to hospital in the first 8 years of life was significantly higher in T allele homozygotes compared to other genotype groups (12.2\% vs. $6.4 \%, \mathrm{p}=0.01$, Table 1 ). In a multiple logistic regression model adjusted for gender, atopic sensitisation and maternal smoking, $\mathrm{T}$ allele homozygotes were significantly more likely to be hospitalized for wheeze/asthma compared to C allele carriers (aOR 2.20 [1.223.99], $\mathrm{p}=0.009$ ).

In the analysis investigating the effect of genotype on the age of first hospital admis- sion with asthma/wheeze, Kaplan-Meier plots suggested an increased risk of hospital admission amongst $\mathrm{T}$ allele homozygotes (Figure 1), with the results of a Cox regression analysis indicating an overall hazard ratio in this genotype group of 1.94 [1.133.33], $\mathrm{p}=0.016$.

Further analysis amongst children with a history of wheezing revealed that the TT genotype was not associated with hospital admission in the first year of life, but increased the risk of admission beyond the first year (OR 2.34 [1.12-4.87], $\mathrm{p}=0.02$, Table 2).

\section{Severe exacerbation of asthma/wheeze}

Children with TT genotype were significantly more likely to have had severe asthma exacerbation compared to those with CC and CT genotype (OR 1.61 [1.04-2.49], $\mathrm{p}=0.03)$. The association remained signifi- 
Table 2 Admission to hospital and severe asthma/wheeze exacerbations by rs7216389 amongst children who wheezed in the first 8 years.

\begin{tabular}{|c|c|c|c|c|}
\hline Outcomes & TT & $\mathrm{CC}+\mathrm{CT}$ & OR $(95 \% \mathrm{Cl})$ & $P$ value \\
\hline $\begin{array}{l}\text { Admission to hospital for } \\
\text { asthma/wheeze in the first year } \\
(n=259)^{*}\end{array}$ & $\begin{array}{l}8 / 78 \\
(10.3 \%)\end{array}$ & $\begin{array}{l}14 / 181 \\
(7.7 \%)\end{array}$ & $1.36(0.55-3.40)$ & 0.5 \\
\hline $\begin{array}{l}\text { Admission to hospital for } \\
\text { asthma/wheeze after the first } \\
\text { year }(n=259)^{*}\end{array}$ & $\begin{array}{l}16 / 78 \\
(20.5 \%)\end{array}$ & $\begin{array}{l}18 / 181 \\
(9.9 \%)\end{array}$ & $2.34(1.12-4.87)$ & 0.02 \\
\hline $\begin{array}{l}\text { Severe asthma/wheeze } \\
\text { exacerbation in the first year of } \\
\text { life }(n=259)^{*}\end{array}$ & $\begin{array}{l}8 / 78 \\
(10.3 \%)\end{array}$ & $\begin{array}{l}18 / 181 \\
(9.9 \%)\end{array}$ & $1.04(0.43-2.49)$ & 0.9 \\
\hline $\begin{array}{l}\text { Severe asthma/wheeze } \\
\text { Exacerbation after the first } \\
\text { year of life }(n=259)^{*}\end{array}$ & $\begin{array}{l}30 / 78 \\
(38.5 \%)\end{array}$ & $\begin{array}{l}52 / 181 \\
(28.7 \%)\end{array}$ & $1.55(0.89-2.71)$ & 0.1 \\
\hline
\end{tabular}

* Analysis conducted among children who wheezed in the first eight years of life only $\mathrm{TT}=$ mutant homozygote; $\mathrm{CC}=$ wild type homozygote; $\mathrm{CT}=$ heterozygote .

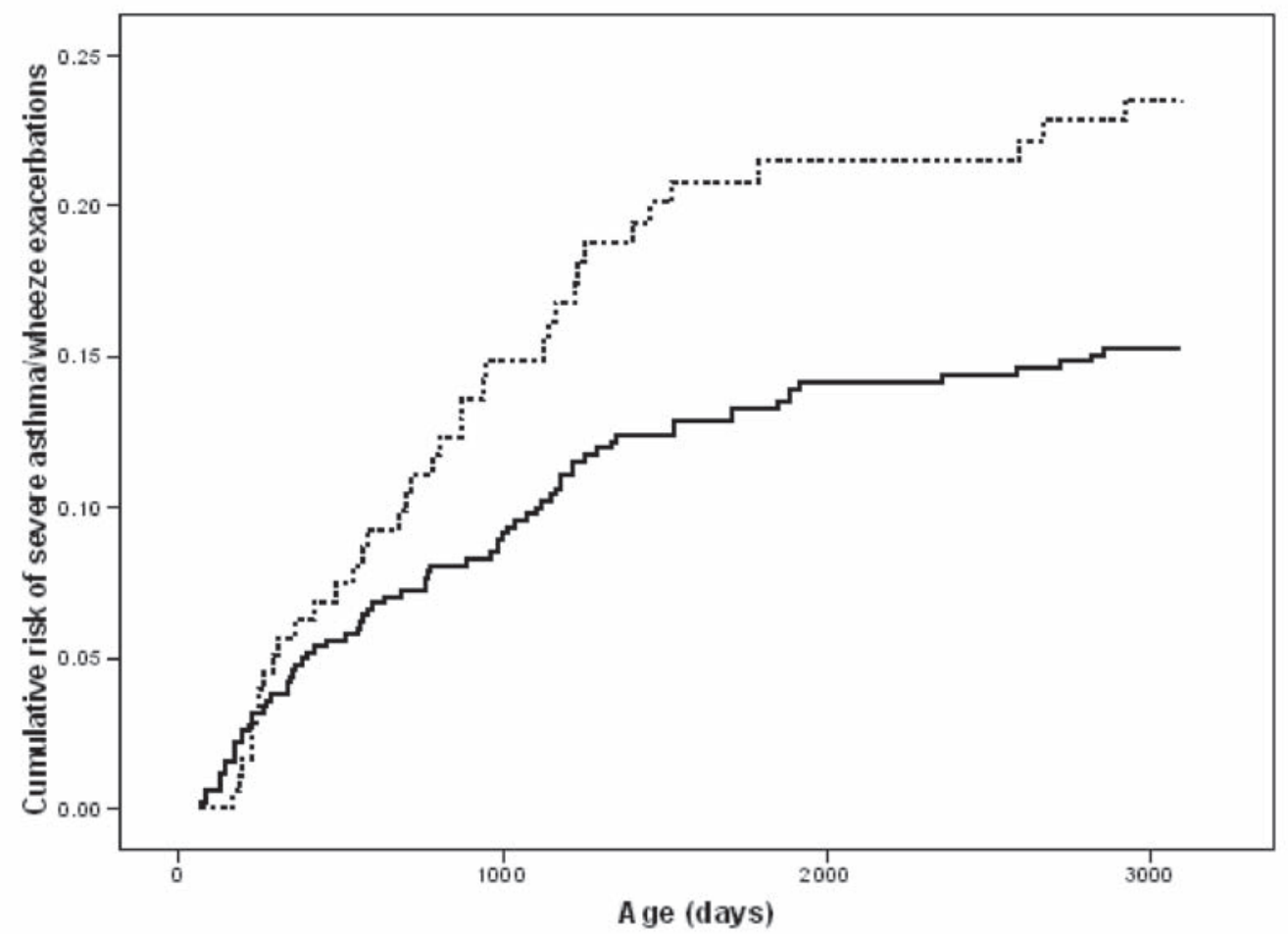

Figure 2 Kaplan-Meier Estimates of Cumulative Risk of severe asthma/wheeze exacerbations in two rs7216389 genotype groups. Dashed line: TT homozygotes; Solid line: CT heterozygotes+ CC homozygotes

cant after adjusting for gender, atopic sensitisation and maternal smoking (aOR 1.73 [1.10-2.73], $\mathrm{p}=0.02)$.
In the analysis investigating the effect of genotype on the age of first severe exacerbation of asthma, Kaplan-Meier plots sug- 
Aida Semic-Jusufagic et al.: A polymorphism in gasdermin B (GSDMB) gene is associated...

Table 3 Allergic sensitization, eczema and rhinitis by rs7216389 in the cohort

\begin{tabular}{|c|c|c|c|c|}
\hline Outcomes & TT & $\mathrm{CC}+\mathrm{CT}$ & OR (95\% Cl) & $P$ value \\
\hline $\begin{array}{l}\text { Atopic (SPT) at age } 3 \\
(n=673)\end{array}$ & $\begin{array}{l}38 / 181 \\
(21.0 \%)\end{array}$ & $\begin{array}{l}103 / 492 \\
(20.9 \%)\end{array}$ & $1.00(0.66-1.53)$ & 1.00 \\
\hline $\begin{array}{l}\text { Atopic (SPT) at age } 5 \\
(\mathrm{n}=723)\end{array}$ & $\begin{array}{l}53 / 189 \\
(28.0 \%)\end{array}$ & $\begin{array}{l}144 / 534 \\
(27.0 \%)\end{array}$ & $1.06(0.73-1.53)$ & 0.8 \\
\hline $\begin{array}{l}\text { Atopic (SPT) at age } 8 \\
(\mathrm{n}=717)\end{array}$ & $\begin{array}{l}57 / 189 \\
(30.2 \%)\end{array}$ & $\begin{array}{l}156 / 528 \\
(29.5 \%)\end{array}$ & $1.03(0.72-1.48)$ & 0.9 \\
\hline $\begin{array}{l}\text { Current eczema at age } 3 \\
(n=746)\end{array}$ & $\begin{array}{l}49 / 201 \\
(24.4 \%)\end{array}$ & $\begin{array}{l}127 / 561 \\
(22.6 \%)\end{array}$ & $1.04(0.72-1.52)$ & 0.8 \\
\hline $\begin{array}{l}\text { Current eczema at age } 5 \\
(\mathrm{n}=774)\end{array}$ & $\begin{array}{l}72 / 201 \\
(35.8 \%)\end{array}$ & $\begin{array}{l}166 / 573 \\
(29.0 \%)\end{array}$ & $1.37(0.97-1.92)$ & 0.07 \\
\hline $\begin{array}{l}\text { Current eczema at age } 8 \\
(n=762)\end{array}$ & $\begin{array}{l}49 / 201 \\
(24.4 \%)\end{array}$ & $\begin{array}{l}127 / 561 \\
(22.6 \%)\end{array}$ & $1.10(0.76-1.61)$ & 0.6 \\
\hline $\begin{array}{l}\text { Eczema on physical } \\
\text { examination at age } 3(n=744)\end{array}$ & $\begin{array}{l}30 / 197 \\
(15.2 \%)\end{array}$ & $\begin{array}{l}66 / 547 \\
(12.1 \%)\end{array}$ & $1.31(0.82-2.09)$ & 0.3 \\
\hline $\begin{array}{l}\text { Eczema on physical } \\
\text { examination at age } 5(n=764)\end{array}$ & $\begin{array}{l}37 / 197 \\
(18.8 \%)\end{array}$ & $\begin{array}{l}68 / 567 \\
(12.0 \%)\end{array}$ & $1.70(1.10-2.63)$ & 0.02 \\
\hline $\begin{array}{l}\text { Eczema on physical } \\
\text { examination at age } 8(n=734)\end{array}$ & $\begin{array}{l}31 / 191 \\
(16.2 \%)\end{array}$ & $\begin{array}{l}58 / 543 \\
(10.7 \%)\end{array}$ & $1.62(1.01-2.60)$ & 0.045 \\
\hline $\begin{array}{l}\text { Current rhinitis at age } 5 \\
(n=769)\end{array}$ & $\begin{array}{l}52 / 201 \\
(25.9 \%)\end{array}$ & $\begin{array}{l}163 / 568 \\
(28.7 \%)\end{array}$ & $0.87(0.60-1.25)$ & 0.5 \\
\hline $\begin{array}{l}\text { Current rhinitis at age } 8 \\
(n=762)\end{array}$ & $\begin{array}{l}58 / 203 \\
(28.6 \%)\end{array}$ & $\begin{array}{l}154 / 559 \\
(27.5 \%)\end{array}$ & $1.05(0.74-1.50)$ & 0.8 \\
\hline
\end{tabular}

$\mathrm{TT}=$ mutant homozygote; $\mathrm{CC}=$ wild type homozygote; $\mathrm{CT}=$ heterozygote

gested an increased risk of severe exacerbation amongst $\mathrm{T}$ allele homozygotes (Figure 2 ), with results of Cox regression analysis indicating an overall hazard ratio of severe asthma exacerbation in this genotype group of 1.53 [1.04-2.27], $\mathrm{p}=0.03$.

Amongst wheezers, there was no significant difference in the risk of having severe asthma exacerbation before or after the first year of life between $\mathrm{T}$ allele homozygotes and other genotype groups $(\mathrm{p}=0.9$ and $\mathrm{p}=0.1$, respectively, Table 2 ).

\section{Allergic sensitisation, rhinitis and eczema}

There was no significant association between rs7216389 and allergic sensitisation or current rhinitis at any time point (Table 3). Interestingly, TT homozygotes were more likely to have had eczema present on physical examination at age 5 and 8 years $(\mathrm{p}=0.02$ and $\mathrm{p}=0.045$, respectively, Table 3$)$.

\section{Discussion}

\section{Principal findings}

This is the first population-based birth cohort study to confirm findings of the association between polymorphisms in rs7216389 SNP and childhood asthma and its severity, and the first study to show the association between this genetic variant and persistent childhood wheezing. We have shown that children with TT genotype of rs7216389 had significantly higher risk of being admitted to hospital for asthma/ wheeze and having severe asthma exacerbations during the first 8 years of life. This risk was specific for hospital admissions occurring after the age of 
one year, but not for those in the first year of life. In addition, $\mathrm{T}$ allele homozygotes were more likely to have had frequent episodes of wheeze and more likely to be using inhaled asthma medication at age 5 and 8 years. We found no association between $\mathrm{T}$ allele of rs7216389 and atopic sensitisation or allergic rhinitis. Although TT genotype was not associated with parentally-reported eczema, it increased the risk of eczema confirmed on physical examination at ages 5 and 8 years.

\section{Limitations and strengths}

We attempted to minimize false positive results due to multiple testing, but we acknowledge that the potential impact of multiple testing on the degree to which conclusions can be considered reliable cannot be fully eliminated. Our analysis was hypothesis-driven and limited to a single genotype comparison in several carefully defined phenotypes. Another limitation of our study is that we do not have a functional explanation for our findings.

The most recent GWAS for asthma identified a different SNP (rs2305480) as the SNP most strongly associated with asthma in this region (29). However, we note that rs 2305480 is in the same LD block as rs7216389, with a D' of 0.99 (3). We therefore did not genotype rs2305480 SNP for this analysis.

The validity of findings from genetic association studies depends on the quality of phenotypic data used. The major strength of our study is that it is set within a population-based birth cohort with high follow-up rate, which gives higher validity in terms of generalizability of the results. The prospective nature of data collection enabled us to accurately assess the presence of wheeze throughout the first 8 years of life, avoiding the likelihood of recall bias. Another strength is that the availability of data from the children's primary care record gave us access to precise and accurate information on the timing and occurrence of hospital admissions for asthma/wheeze and severe asthma exacerbations.

\section{Interpretation}

Our finding that children with TT genotype have an increased risk of wheezing and severe asthma/wheeze exacerbations in early life is consistent with the findings by Bisgaard et al (13). In this high-risk birth cohort study, the hazard ratio among $\mathrm{T}$ allele homozygotes compared to $\mathrm{C}$ allele carriers for asthma was 1.88 [1.15-3.07], severe exacerbations 2.66 [1.58-4.48], and recurrent wheeze 1.64 [1.05-2.59]. However, neither we nor Bisgaard et al. (13) found an association between rs7216389 polymorphisms and atopic sensitisation or allergic rhinitis, suggesting that genetic predisposition for asthma differs from that for atopy and allergic rhinitis. We did not find an association between rs7216389 polymorphisms and hospital admissions for wheezing in the first year of life, most likely due to the fact that most children who wheeze in the first year of life have viral infection-induced wheeze and do not continue wheezing beyond the first year (30).

Our finding of the association between rs7216389 polymorphisms and persistent wheezing is comparable with the recent study which found strong association of this SNP with early-onset asthma (0-5 years) (31). In addition, in this study $\mathrm{T}$ allele was associated with the severity of early-onset asthma defined on the basis of symptom frequency and medication use. Furthermore, amongst a population of severe asthmatics, the T allele of rs7216389 was associated with childhood asthma-onset disease (32). Similarly, we found that the use of asthma medication was significantly more common amongst children who were $\mathrm{T}$ allele homozygotes. Although asthma severity and severe asthma exacerbations reflect different 
aspects of asthma control, they both highlight a group of children who may be less responsive to conventional therapy and more susceptible to asthma exacerbations.

What could be a plausible biological mechanism for the observed association? Although there is no clear explanation of the function of the GSDMB gene, two studies found a relationship between variants in rs7216389 and ORMDL3 transcript levels, speculating that rs7216389 SNP could be regulating the expression of the ORMDL3 gene product $(3,31)$. The function of the ORMDL3 gene product has only been recently described (33). ORMDL3 encodes a transmembrane protein embedded in the wall of the endoplasmic reticulum (ER) which regulates $\mathrm{Ca}^{2+}$ influx into ER and is essential for protein folding. Overexpression of ORMDL3 product inhibits the influx of $\mathrm{Ca}^{2+}$ ions into the ER via sarco-endoplasmic reticulum $\mathrm{Ca}^{2+}$ pump which results in unfolded protein response (33), and unfolded protein response may cause transcription of genes able to induce inflammation (34).

A recent study of polymorphisms in the 17 q21 region and its effect on gene expression levels in cord blood samples of healthy neonates found that T-allele homozygotes of rs7216389 already had an increased expression of the ORMDL3 gene compared to other genotypes at birth (35). The expression of ORMDL3 significantly increased after in vitro cord blood mononuclear cell stimulation with Der p 1 allergen (35). In addition, T-allele homozygotes for rs7216389 and three other SNPs in 17q21 region had increased baseline IL-17 cytokine production. IL-17 can be secreted by many cell subsets (e.g. $\mathrm{T}_{\mathrm{H}} 17$ and $\mathrm{T}_{\mathrm{H}} 2$ ) and has been implicated in pathophysiology of both autoimmune diseases and asthma (36). A proportion of asthmatic individuals who have poorly controlled asthma have increased level of IL-17 in their airways that correlates with the degree of neutrophilic inflammation in their airways as well as airway hyperreactivity (however the exact pathophysiology leading to this type of inflammation remains to be elucidated) (37).

A recent GWA study on white blood cell (WBC) phenotypes found that total WBC and neutrophil counts were strongly associated with chromosome 17q21 region close to ORMDL3 (38).

We found a significant association between rs7216389 TT genotype and eczema present on physical examination. Apart from one negative report from the Danish high-risk cohort (13), there are no other studies that have looked into the association between childhood eczema and SNPs in GS$D M B$ region. This finding warrants replication in other populations.

\section{Conclusion}

Our data indicate that children who are T-allele homozygotes for rs7216389 have increased risk of persistent wheezing, are more likely to use asthma medication and to experience severe asthma exacerbations and are more likely to be admitted to hospital because of acute attack of asthma compared to $\mathrm{C}$ allele carriers. In addition, amongst asthmatic children, the likelihood of severe exacerbation requiring hospital admission after the first year of life is higher amongst T-allele homozygotes for rs7216389.

\section{Acknowledgements \\ The authors would like to thank the children and their parents for their continued support and enthusiasm. We greatly appreciate the commitment they have giv- en to the project. We would also like to acknowledge the hard work and dedication of the study team (re- search fellows, nurses, physiologists, technicians and clerical staff).}

Conflict of interest: The authors declare that they have no conflict of interest. This study was supported by Asthma UK Grant No 04/014 and Moulton Charitable Trust, and is currently supported by MRC Grant G0601361. 
Authors' contributions: Analysis and interpretation of data, drafting of manuscript: ASJ; Conception and design of study, critical revision of manuscript: AC and AS; Genotyping: JH; All authors equally contributed to the final version of manuscript.

\section{References}

1. Duffy DL, Martin NG, Battistutta D, Hopper JL, Mathews JD. Genetics of asthma and hay fever in Australian twins. Am Rev Respir Dis. 1990; 142:1351-8.

2. Ober C, Hoffjan S. Asthma genetics 2006: the long and winding road to gene discovery. Genes Immun. 2006;7:95-100.

3. Moffatt MF, Kabesch M, Liang L, Dixon AL, Strachan D, Heath S, et al. Genetic variants regulating ORMDL3 expression contribute to the risk of childhood asthma. Nature. 2007;448:470-3.

4. Tamura M, Tanaka S, Fujii T, Aoki A, Komiyama $\mathrm{H}$, Ezawa K, et al. Members of a novel gene family, Gsdm, are expressed exclusively in the epithelium of the skin and gastrointestinal tract in a highly tissue-specific manner. Genomics. 2007;89:618-29.

5. Saeki N, Usui T, Aoyagi K, Kim DH, Sato M, Mabuchi $\mathrm{T}$, et al. Distinctive expression and function of four GSDM family genes (GSDMA-D) in normal and malignant upper gastrointestinal epithelium. Genes Chromosomes Cancer. 2009;48:261-71.

6. Hjelmqvist L, Tuson M, Marfany G, Herrero E, Balcells S, Gonzalez-Duarte R. ORMDL proteins are a conserved new family of endoplasmic reticulum membrane proteins. Genome Biol 2002; 3:RESEARCH0027.

7. Galanter J, Choudhry S, Eng C, Nazario S, Rodriguez-Santana JR, Casal J, et al. ORMDL3 gene is associated with asthma in three ethnically diverse populations. Am J Respir Crit Care Med. 2008;177:1194-200.

8. Hirota T, Harada M, Sakashita M, Doi S, Miyatake A, Fujita K, et al. Genetic polymorphism regulating ORM1-like 3 (Saccharomyces cerevisiae) expression is associated with childhood atopic asthma in a Japanese population. J Allergy Clin Immunol. 2008;121:769-70.

9. Madore AM, Tremblay K, Hudson TJ, Laprise C. Replication of an association between 17q21 SNPs and asthma in a French-Canadian familial collection. Hum Genet 2008;123:93-5.

10. Leung TF, Sy HY, Ng MC, Chan IH, Wong GW, Tang NL, et al. Asthma and atopy are associated with chromosome 17q21 markers in Chinese children. Allergy. 2009;64:621-8.
11. Wu H, Romieu I, Sienra-Monge JJ, Li H, del Rio-Navarro BE, London SJ. Genetic variation in ORM1-like 3 (ORMDL3) and gasderminlike (GSDML) and childhood asthma. Allergy. 2009;64:629-35.

12. Tavendale R, Macgregor DF, Mukhopadhyay S, Palmer CN. A polymorphism controlling ORMDL3 expression is associated with asthma that is poorly controlled by current medications. J Allergy Clin Immunol. 2008;121:860-3.

13. Bisgaard H, Bonnelykke K, Sleiman PM, Brasholt M, Chawes B, Kreiner-Moller E, et al. Chromosome 17 q21 gene variants are associated with asthma and exacerbations but not atopy in early childhood. Am J Respir Crit Care Med. 2009;179:179-85.

14. Custovic A, Simpson BM, Murray CS, Lowe L, Woodcock A. The National Asthma Campaign Manchester Asthma and Allergy Study. Pediatr Allergy Immunol. 2002; 13 Suppl 15:32-7.

15. Lowe L, Murray CS, Custovic A, Simpson BM, Kissen PM, Woodcock A. Specific airway resistance in 3-year-old children: a prospective cohort study. Lancet. 2002;359:1904-8.

16. Lowe L, Murray CS, Martin L, Deas J, Cashin E, Poletti G, et al. Reported versus confirmed wheeze and lung function in early life. Arch Dis Child. 2004; 89:540-3.

17. Murray CS, Woodcock A, Smillie FI, Cain G, Kissen P, Custovic A. Tobacco smoke exposure, wheeze, and atopy. Pediatr Pulmonol. 2004;37:492-8.

18. Nicolaou N, Poorafshar M, Murray C, Simpson A, Winell H, Kerry G, et al. Allergy or tolerance in children sensitized to peanut: prevalence and differentiation using component-resolved diagnostics. J Allergy Clin Immunol. 2010;125:191-7 e1-13.

19. Lowe LA, Simpson A, Woodcock A, Morris J, Murray CS, Custovic A. Wheeze phenotypes and lung function in preschool children. Am J Respir Crit Care Med. 2005;171:231-7.

20. Martinez FD, Wright AL, Taussig LM, Holberg CJ, Halonen M, Morgan WJ. Asthma and wheezing in the first six years of life. The Group Health Medical Associates. N Engl J Med. 1995;332:133-8.

21. Nicolaou NC, Simpson A, Lowe LA, Murray CS, Woodcock A, Custovic A. Day-care attendance, position in sibship, and early childhood wheezing: a population-based birth cohort study. J Allergy Clin Immunol. 2008;122:500-6 e5.

22. Reddel HK, Taylor DR, Bateman ED, Boulet LP, Boushey HA, Busse WW, et al. An official American Thoracic Society/European Respiratory Society statement: asthma control and exacerbations: standardizing endpoints for clinical asthma trials 
and clinical practice. Am J Respir Crit Care Med. 2009;180:59-99.

23. Bray MS, Boerwinkle E, Doris PA. High-throughput multiplex SNP genotyping with MALDI-TOF mass spectrometry: practice, problems and promise. Hum Mutat. 2001;17:296-304.

24. Yang H, Wang H, Wang J, Cai Y, Zhou G, He F, et al. Multiplex single-nucleotide polymorphism genotyping by matrix-assisted laser desorption/ ionization time-of-flight mass spectrometry. Anal Biochem. 2003;314:54-62.

25. Tost J, Gut IG. Genotyping single nucleotide polymorphisms by mass spectrometry. Mass Spectrom Rev. 2002;21:388-418.

26. Custovic A, Simpson BM, Simpson A, Kissen P, Woodcock A. Effect of environmental manipulation in pregnancy and early life on respiratory symptoms and atopy during first year of life: a randomised trial. Lancet. 2001;358:188-93.

27. Simpson A, Simpson B, Custovic A, Craven M, Woodcock A. Stringent environmental control in pregnancy and early life: the long-term effects on mite, cat and dog allergen. Clin Exp Allergy. 2003;33:1183-9.

28. Woodcock A, Lowe LA, Murray CS, Simpson BM, Pipis SD, Kissen P, et al. Early life environmental control: effect on symptoms, sensitization, and lung function at age 3 years. Am J Respir Crit Care Med. 2004;170:433-9.

29. Moffatt MF, Gut IG, Demenais F, Strachan DP, Bouzigon E, Heath S, et al. A large-scale, consortium-based genomewide association study of asthma. N Engl J Med. 2010;363:1211-21.

30. Brand PL, Baraldi E, Bisgaard H, Boner AL, Castro-Rodriguez JA, Custovic A, et al. Definition, assessment and treatment of wheezing disorders in preschool children: an evidence-based approach. Eur Respir J. 2008;32:1096-110.

31. Halapi E, Gudbjartsson DF, Jonsdottir GM, Bjornsdottir US, Thorleifsson G, Helgadottir H, et al. A sequence variant on $17 q 21$ is associated with age at onset and severity of asthma. Eur J Hum Genet. 2010;18:902-8.

32. Binia A, Khorasani N, Bhavsar PK, Adcock I, Brightling CE, Chung KF, et al. Chromosome 17q21 SNP and severe asthma. J Hum Genet. 2011;56:97-8.

33. Cantero-Recasens G, Fandos C, Rubio-Moscardo F, Valverde MA, Vicente R. The asthma-associated ORMDL3 gene product regulates endoplasmic reticulum-mediated calcium signaling and cellular stress. Hum Mol Genet. 2010;19:111-21.

34. Zhang K, Kaufman RJ. From endoplasmic-reticulum stress to the inflammatory response. Nature. 2008;454:455-62.

35. Lluis A, Schedel M, Liu J, Illi S, Depner M, von Mutius E, et al. Asthma-associated polymorphisms in 17q21 influence cord blood ORMDL3 and GSDMA gene expression and IL-17 secretion. J Allergy Clin Immunol. 2011;127:1587-94 e6.

36. Chatila TA, Li N, Garcia-Lloret M, Kim HJ, Nel AE. T-cell effector pathways in allergic diseases: transcriptional mechanisms and therapeutic targets. J Allergy Clin Immunol. 2008;121:812-23; quiz 24-5.

37. Wang YH, Wills-Karp M. The Potential Role of Interleukin-17 in Severe Asthma. Curr Allergy Asthma Rep. 2011;11:388-94

38. Nalls MA, Couper DJ, Tanaka T, van Rooij FJ, Chen $\mathrm{MH}$, Smith AV, et al. Multiple Loci are associated with white blood cell phenotypes. PLoS Genet. 2011;7:e1002113. 